\title{
THE EFFECT OF COMBINATION OF NUMBER HEAD TOGETHER AND TWO STAY TWO STRAY LEARNING MODELS ON MATHEMATICAL LEARNING OUTCOMES AND ACTIVENESS OF SENIOR HIGH SCHOOL STUDENTS
}

\author{
Andi Kaharuddin ${ }^{1}$, Nining Hajeniati ${ }^{2}$ \\ ${ }^{1,2}$ Mathematics Education, Faculty of Pedagogy and Teacher Training, Universitas \\ Lakidende Unaaha, Indonesia
}

Corresponding author: andikaharuddinunismuhmks@gmail.com*

\begin{tabular}{|c|c|}
\hline Article Info & Abstract \\
\hline $\begin{array}{l}\text { Received : } 28 \text { September } 2020 \\
\text { Accepted : } 08 \text { October } 2020 \\
\text { Published : } 22 \text { October } 2020\end{array}$ & $\begin{array}{l}\text { An engaging learning process will affect learning outcomes } \\
\text { and student activeness during the learning process. The } \\
\text { present study was conducted to investigate the effect of the } \\
\text { combinatory use of Number Head Together and Two Stay Two }\end{array}$ \\
\hline $\begin{array}{l}\text { Keywords: Learning Effect, } \\
\text { Combination of Learning } \\
\text { Models, Number Head Together, } \\
\text { Two Stay Two Stray }\end{array}$ & $\begin{array}{l}\text { Stray learning models on the scores of high school students } \\
\text { mathematical tests and learning activeness. It was an } \\
\text { experimental-based study with One Group Pre-test Post-test } \\
\text { design. The population of this study was all high school } \\
\text { students in Kendari, with Cluster Random Sampling as the } \\
\text { method to choose the sample. Final test and observation were } \\
\text { used as instruments to collect data. The data were analyzed } \\
\text { using descriptive and inferential statistics with the One- } \\
\text { Sample t-test. Results showed that (1) the combinatory use of } \\
\text { both learning models improved learning outcome by } \\
\text { increasing students' average test scores from an average score } \\
\text { of } 68 \text { (pre-test) to an average of } 83 \text { (post-test) with a gain } \\
\text { value of } 0.71 \text {; (2) the learning models had a positive influence } \\
\text { on student activeness during the learning process, proven by a } \\
\text { score of } 3.3 \text { (positive category). It was also evidenced by the } \\
\text { results of the } t \text {-test showing that the t-count score was greater } \\
\text { than the t-table. Therefore, the combinatory use of Number Head } \\
\text { Together and Two Stay Two Stray learning models has a } \\
\text { significant effect on increasing the learning outcome and } \\
\text { learning activeness of high school students in the mathematic } \\
\text { class. }\end{array}$ \\
\hline
\end{tabular}

International Journal of Educational Best Practices (IJEBP)

Vol. 4 No. 2 October 2020

ISSN: 2581-0847

DOI: $10.32581 /$ ijebp.v4n2.p78-87 


\section{INTRODUCTION}

One of the teacher's obligations is to arrange an engaging learning process. In the context of the mathematics learning process, the use of technology and information media in learning is especially helpful since they help teachers in delivering teaching in an engaging fashion (Batubara, 2019). Because mathematics is an abstract concept, it is necessary to employ appropriate technology and information media in the process of designing an engaging learning experience (Fitriani, Saragih, \& Murni, 2020).

The teaching and learning process of mathematics so far is dominantly one-way teachers transfer knowledge to the students. As a consequence, only the fast-learning students can successfully acquire lessons, which explains the wide variation in the students' final semester scores. Data from students' daily quiz show that only three students obtained 80 or above and the rest of the class scored below the minimum passing score. After investigating some mathematics teachers across high schools in Kendari city, the less optimal application of the 2018 revision of the 2013 curriculum was found to be one of the underlying causes of students' poor performance. Most of the teachers stated that the curriculum is too complicated. As a result, they designed learning activities that lead students to work independently, for example, by distributing and using individual student worksheets. These kinds of activities eliminate interaction between students, groups, and peer tutors, whereas humans essentially cannot live without the help of others (Habibahi, Aisyiyah, \& Ningrum, 2012).

The aforementioned problem requires a solution so that students can develop mutual trust and help one another in the learning process. Kaharuddin (2019) said that an optimal learning process will occur if teachers lead students to work together in groups to solve a problem. Without mutual assistance, the students' learning outcome evaluated from their test scores will be diverse, and some of them will be less motivated in the learning process. One of the solutions for the problem is to apply the concept of peer learning, a learning model that stimulates passion, activities, involvement, and teamwork, which can help improve students' overall learning outcomes. Umar, Kaharuddin, \& Erfan (2020) argue that effective learning requires students to study in groups without discrimination based on ethnicity, race, and religion, and it is done in a sustained manner. The two learning models, namely Number Head Together and Two Stay Two Stray, represent that type of learning.

Number Head Together is a fun but serious learning concept (Pinontoan, 2019), while Two Stay Two Stray is the concept of group learning, with students exchanging their learning partners (Huda et al., 2020). When combined, the two models will produce a fun, engaging learning experience that can cope with the student boredom in learning and overcome the gap of test scores among students. No literature, to the best of our knowledge, has ever studied how the two learning models, when combined, affect

\section{International Journal of Educational Best Practices (IJEBP)}

Vol. 4 No. 2 October 2020

ISSN: 2581-0847

DOI: $10.32581 /$ ijebp.v4n2.p78-87 
learning outcomes, but several researchers have proven that both models can improve teamwork, activities, and learning outcome. Turmuzi's (2017) study on the use of Number Head Together to improve students 'critical thinking skills concludes that the learning model, in addition to increased critical thinking skills, developed students' collaboration and activities. Similarly, Anwar, Ari, Sri, Widodo, \& Pendahuluan (2018) found that the Number Head Together model increased students' learning achievement. Concerning studies on Two Stay Two Stray, Suwangsih, Budiarti, Ruskandi, Hendawati, \& Majid (2019) argue that the model improved students' language and communication skills. Similar results were also demonstrated by Sudrajat, Iasha, \& Femayati (2018) in that the Two Stay Two Stray model affected improving students' activeness and learning outcomes.

The above rationale led us to study the effect of the combination of Number Head Together and Two Stay Two Stray learning models on learning outcomes and student activeness in high school.

\section{METHODOLOGY}

The study was conducted in Kendari, Southeast Sulawesi with all high school students sitting in the 2019/2020 academic year as the population of the study. The Cluster Random Sampling technique was employed, and students in class $\mathrm{XI}_{\mathrm{b}}$ in $\mathrm{SMA} 4$ Kendari were selected as the sample of the study. It was an experimental-based study with a One Group Pre-test Post-test research design.

Table 1. One Group Pre-test Post-test research design

\begin{tabular}{|c|c|c|}
\hline Pre-test & Treatment & Post-test \\
\hline $\mathrm{T}_{1}$ & $\mathrm{X}$ & $\mathrm{T}_{2}$ \\
\hline
\end{tabular}

Source: Creswell (2012)

Lesson plans and power-point slides were used as learning tools. Based on the combination of Number Head Together and Two Stay Two Stray models, students first were put into several groups. They were then given a problem to discuss, following which they discussed the problem in pairs within those groups. Afterward, the students drew conclusions based on the numbering of figures in heads (the results of the research). Data were collected through (1) pre-test and post-test to measure the change in the students' learning performance and (2) observation sheets to measure student activeness during the learning process. To analyze the results, both descriptive and inferential statistics with the One-Sample $t$-Test was employed in this study.

\section{International Journal of Educational Best Practices (IJEBP)}




\section{FINDINGS}

The results of the descriptive analysis of the results of pre-test and post-test are provided in Graph 1.
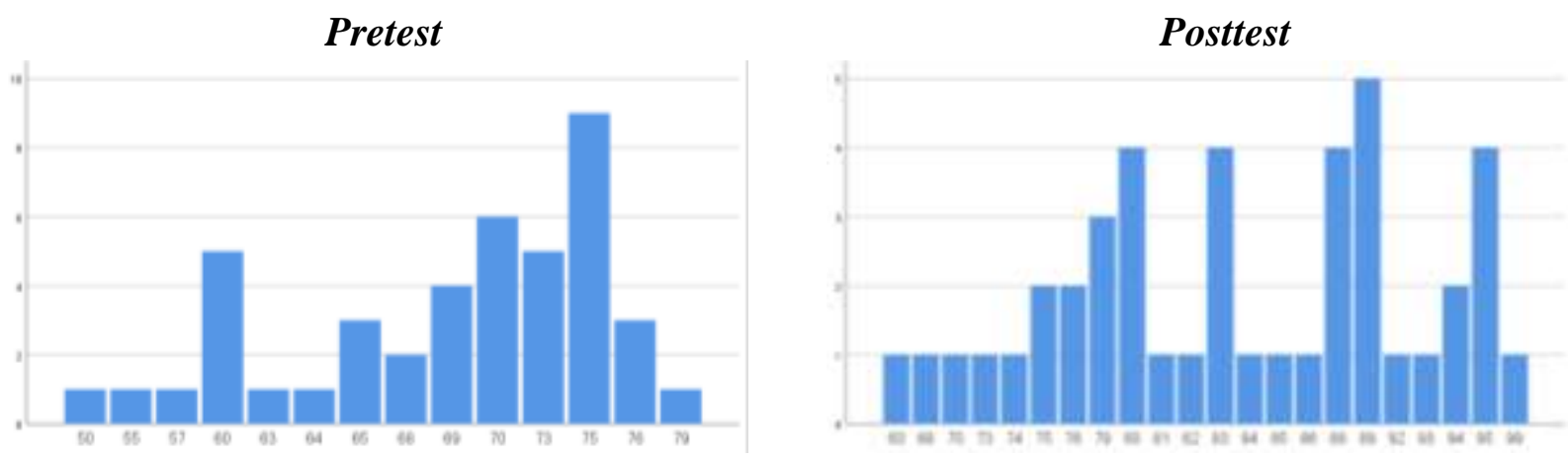

Graph 1. Results of pre-test and post-test

The graph shows that there was a significant increase in the students' test scores, and the scores were evenly distributed to all members of class $\mathrm{XI}_{\mathrm{b}}$, with an average pre-test score of 68 and an average post-test score of 83. The increase in the score was obtained from the Gain test with the formula $=\frac{\text { Score Posttest-Score Pretest }}{\text { Maximum Score-Score Pretest }}$. The G score obtained was 0.71 , which means that the increase after the application of both learning methods is categorically high. This finding provided a provisional assumption that the combination of Number Head Together and Two Stay Two Stray models descriptively has a positive effect on the students' test scores.

After the descriptive analysis, the inferential analysis was conducted by using the normality test. It was then followed by the $t$-test with the help of Statistical Product and Service Solutions. The results of the test are given in Table 2:

Table 2. One-Sample Test

\begin{tabular}{|c|c|c|c|c|c|}
\hline \multicolumn{9}{|c|}{ Test Value = 75 } \\
\hline \multirow{2}{*}{$\mathrm{t}$} & \multirow{2}{*}{ Df } & \multirow{2}{*}{ Sig. (2 tailed) } & \multirow{2}{*}{$\begin{array}{c}\text { Mean } \\
\text { Difference }\end{array}$} & \multicolumn{2}{|c|}{$\begin{array}{c}\text { 95\% Confidence Interval of the } \\
\text { Difference }\end{array}$} \\
\cline { 5 - 6 } & & & & Lower & Upper \\
\hline 6,889 & 42 & 0,00 & 8,791 & 6,22 & 11,37 \\
\hline
\end{tabular}

Source: Results of the Data Analysis using SPSS

Table 2 above suggests that the $t$ score ( $\mathrm{t}_{\text {-count }}$ ), which represents the quality of the effect of both learning models, was 6,889. The degree of freedom, also called the df score, obtained was 42. This score represents the amount of information used to estimate the increase in the students' test scores. Lastly, the study found the two-sided test 
significance value of 0.00 . Since the two-sided significant value was lower than 0.05 , it can be concluded that inferentially the combination of Number Head Together and Two Stay Two Stray has a positive effect on increasing the students' scores.

Table 3 provides the results of the observation of student activeness in the learning process.

Table 3. Results of the Observation of Student Activeness

\begin{tabular}{|c|c|}
\hline Activeness Score & Category \\
\hline 3,3 & Positive \\
\hline
\end{tabular}

Source: Results of the study

Table 3 shows that student activeness during the learning process was 3.3, which is categorically positive. What the score means is that the level of student activeness, cooperation, mutual help, and mutual trust was extremely high. Score 3.3 also indicates that students were interested in the learning models. Therefore, it can be concluded that the combination of both Number Head Together and Two Stay Two Stray models has a positive effect on student activeness in the learning process.

Therefore, based on the results of descriptive and inferential analyses, the use of both the Number Head Together and the Two Stay Two Stray models generally improved students' scores from pre-test (68) to post-test (83) and student activeness (categorically positive) during the learning process in class $\mathrm{XI}_{\mathrm{b}}$ of $\mathrm{SMA} 4$ Kendari.

\section{DISCUSSION}

The learning outcome is a benchmark for the success of a teaching and learning process. Whether a learning process has been successfully conducted is seen from the increase in the students' final scores. The results of the pre-test before the integration of the two learning models produced an average final score of 68 , which was far below the passing score set by the school (80). A deeper investigation of the students whose pre-test scores ranged between 50 and 65 shows that most of the students secretly used the feature of the calculator in their smartphones during the learning process, which implies that they struggled to do some mathematical exercises such as adding, multiplying, and dividing numbers. When doing the research, we taught the students not to depend on their smartphone by giving a quiz that encouraged them to do simple mathematical operations at the end of the class and awarding prizes to those who managed to provide correct answers. This activity trained the left brain of these students.

Sequences and series are basic lessons that students will need to study on an ongoing basis. This is evident from some of the questions that students have to answer in college 
admission tests. It is this reason that motivates us to measure the level of students' understanding of mathematical topics, especially in these lessons. Mastering the lessons will help students in their process to enroll in higher education institutions. To motivate students to learn, we made use of attractive PowerPoint slides and created a liberating learning atmosphere in the sense that there is no pressure from the teachers in the process of teaching and learning process. By doing this, the goal of education as stated by the Minister of Education and Culture in his national education day speech, which is to "create a liberating learning atmosphere", can hopefully be achieved.

Before the post-test was conducted, students had learned about some basic knowledge of sequences and series through collaborative study in groups. As a result, the students' average scores increased from 68 (pre-test) to 83 (post-test) with a difference in the Gain value up to 0.71 . The findings provide evidence that the combination of both learning models successfully increased the students' test scores until they passed the minimum passing score of 80. After conducting the post-test, we reviewed the understanding of students who scored between 60 and 70 and discovered a new finding. The students are not good at mathematics, but they learned from their peers. The collaborative learning experience, thus, has immensely helped them to the point that they were able to increase their score in the post-test.

The high increase in the score of students' test due to the application of the engaging and fun learning models is proven from the observation of student activeness in the learning process, which was categorically positive. The finding suggests that the activeness of students in the class has a direct impact on the learning outcome. The results of observation demonstrate that some students, especially in class $\mathrm{XI}_{\mathrm{b}}$ of SMA 4 Kendari, preferred to study in groups or pairs. It was also found, based on the results of interviews with several students, that the students' enthusiasm to learn resulted from study groups that were randomly formed without discrimination based on their gender and level of intelligence. Those who have a better mastery of the lessons in the study groups helped those who struggled in the class.

Nevertheless, some students criticized group allocation because it was considered unfair. It turns out that the students were paired with other students in the class with whom they had a personal issue. Thus, it was a personal issue of the students instead of an issue with the learning models. Other students in the class found learning in group fun.

The findings and the discussion above demonstrate that the measure of learning success is seen from the increase in the students' final test scores. The results of the present study provide evidence that increase descriptively and inferentially. Moreover, student activeness was also found to be categorically positive. Therefore, it is safe to say that the combination of Number Head Together and Two Stay Two Stray models has a positive effect on the learning outcome and student activeness in the learning process.

\section{International Journal of Educational Best Practices (IJEBP)}

Vol. 4 No. 2 October 2020

ISSN: 2581-0847

DOI: $10.32581 /$ ijebp.v4n2.p78-87 
The results of the present study are in line with Suparlan (2011), which suggests that the experimental results of Number Head Together and Two Stay Two Stray improve student achievement and activeness. The results are also consonant with Nurhasannah (2016), which found that the application of Two Stay Two Stray with the Number Head Together method improves students' skills, activeness, and learning outcome. What makes the present study differs from the mentioned studies lies in the novelty of its results. This study concludes that the combination of two learning models, Number Head Together and Two Stay Two Stray, positively affected students' final test scores and student activeness in the learning process.

\section{CONCLUSION}

Based on the background, results, and discussion, the study concludes that the combinatory use of Number Head Together and Two Stay Two Stray learning models increased (1) students' average test scores from 68 (pre-test) to 83 (post-test) with a gain value of 0.71 and (2) student activeness, proven by the score 3.3 (positive category). It is also evidenced by the results of the $t$-test where the $t_{\text {-count }}$ score was greater than $t_{\text {he }}$ table score. Hence, the combination of Number Head Together and Two Stay Two Stray learning models generally has a significant effect on students' learning outcomes and learning activeness in class.

After understanding that both learning models managed to have a significant effect on students' learning outcomes and student activeness in class, it is expected that the results obtained from the study can be used as a reference or literature for further research and as a learning model in a class by improving weaknesses in the procedures in running the Number Head Together and Two Stay Two Stray learning models and developing advanced teaching materials.

\section{ACKNOWLEDGMENT}

Researchers would like to thank the Ministry of Research and Technology of the Republic of Indonesia for providing research grants for beginner lecturers, due to which this research could be successfully carried out.

\section{REFERENCES}

Adhini, I. N. (2017). The Use Numbered Head Together Technique on Students'

International Journal of Educational Best Practices (IJEBP)

Vol. 4 No. 2 October 2020

ISSN: 2581-0847

DOI: 10.32581/ijebp.v4n2.p78-87 
Reading Ability in Narrative Text Collaborative/Cooperative Learning. English Language and Literature International Conference (ELLIC), 124-128.

Adianto, S. (2018). Increased Activity, Motivation, and Learning Outcomes Mathematics with Learning Model Cooperative Type Numbered Head Together in Grade III Students. IJECA (International Journal of Education and Curriculum Application), 1(3), 35. https://doi.org/10.31764/ijeca.v1i3.2123

Anwar, K., Ari, T., Sri, S., Widodo, A., \& Pendahuluan, A. (2018). Pengaruh Model Pembelajaran Kooperatif Tipe Numbered Heads Together ( Nht ) Terhadap Prestasi Belajar Matematika Siswa. Prosiding Seminar Nasional Etnomatnesia, (6), 790-794.

Batubara, N. A. (2019). the Effect of Using Cabri 3Dv2Plus Software With Cooperative Interaction Setting Learning Model on Students' Mathematical Understanding in Transformation Materials. International Journal of Educational Best Practices, 3(1), 50. https://doi.org/10.31258/ijebp.v3n1.p50-61

Creswell, J. W. (2012). Educational Research Planning, Conducting, and Evaluating Quantitative and Qualitative Research (Fourth Edi; P. A. Smith, Ed.). Boston Columbus Indianapolis New York San Francisco Upper Saddle River Amsterdam Cape Town Dubai London Madrid Milan Munich Paris Montreal Toronto Delhi Mexico City São Paulo Sydney Hong Kong Seoul Singapore Taipei Tokyo: Pearson.

Ervin Tamta Lirnawati, Mardiyana, D. R. S. S. (2017). The Efforts to Improve Mathematics Learning Activity Using Cooperative Learning Model Type Two Stay Two Stray in Linear Program Material Student Class XA SMK Muhammadiyah 1 Kalasan. In Juhansar \& T. Widodo (Eds.), Proceeding of the 5th International Seminar on Quality and Affordable Education. J1. Ringroad Utara, Jombor, Sleman - Yogyakarta: Faculty Of Education Campus 1 Universitas Teknologi Yogyakarta Jl.

Fitriani, I., Saragih, S., \& Murni, A. (2020). Developing Learning Documents Using Assure Design With Problem-Solving Strategy On Social Arithmetic Materials To Increase Mathematical Problem-Solving Ability. International Journal of Educational Best Practices, 4(1), 53-63. https://doi.org/10.32581/ijebp.v4n1.p5363

Habibahi, U., Aisyiyah, N., \& Ningrum, L. I. (2012). Studi Tentang Status Perkawinan Mahasiswa Reguler Pgsd Tegal Hubungannya Dengan Prestasi Akademik. Journal of Elementary Education, 1(1).

Harahap, K. A., \& Surya, E. (2017). Application of Cooperative Learning Model With Type of Two Stays Two Stray to Improve Results of Mathematics Teaching. International Journal of Sciences: Basic and Applied Research (IJSBAR), 33(2), 
$156-165$.

Hendrayati, H., Egryas, R., \& Achyarsyah, M. (2018). The Trial of the Cooperative Learning Models of Two Stay-Two Stray and Talking Stick on Students' Mathematical Communication. Advances in Social Science, Education and Humanities Research, 253(Aes 2018), 317-321. https://doi.org/10.2991/aes18.2019.74

Huda, S., Yasin, M., Fitri, A., Syazali, M., Supriadi, N., Umam, R., \& Jermsittiparsert, K. (2020). Numerical Ability Analysis: The Impact of the Two Stay-Two Stray Learning Model on the Sequence and Series Topic in Islamic Boarding School. Journal of Physics: Conference Series, 1467(1). https://doi.org/10.1088/1742$6596 / 1467 / 1 / 012002$

Kaharuddin, A. (2019). Effect of Problem Based Learning Model on Mathematical Learning Outcomes of 6th Grade Students of Elementary School Accredited B in Kendari City. International Journal of Trends in Mathematics Education Research, 1(2), 43-46. https://doi.org/10.33122/ijtmer.v1i2.14

Naibaho, L. (2020). the Effectiveness of Number Head Together Strategy on Improving Students' English Achievement At Xyz School. International Journal of Research -GRANTHAALAYAH, 7(10), https://doi.org/10.29121/granthaalayah.v7.i10.2019.406

Nurhasannah. (2016). Penerapan Metode Two Stay Two Stray (TSTS) dengan Metode Number Head Together (NHT) dalam Meningkatkan Aktivitas Belajar Siswa. Bandung.

Pinontoan, M. (2019). Number Head Together Model in Social Learning. Advances in Social Science, Education and Humanities Research 5th International Conference on Education and Technology (ICET 2019) Number, 382(Icet), 212-216. https://doi.org/10.2991/icet-19.2019.54

Sinta, T., Putratama, A. A., \& Pratama, F. W. (2019). International Journal of Active Learning A Comparison of The Learning Outcomes Resulted from Jigsaw and TSTS Learning Models Viewed from The Students ' Self Regulated Learning. International Journal of Active Learning, 4(2), 78-87.

Sudrajat, A., Iasha, V., \& Femayati, F. (2018). The Influence of the Use of Cooperative Learning Model Jigsaw \& Two Stay Two Stray and the Learning Interest Result on 5th Grade Social Science. Proceeding Book of 1st International Conference on Educational Assessment and Policy, 2, 28-33. https://doi.org/10.26499/iceap.v2i1.92

Suparlan, A. (2011). Eksperimentasi Pembelajaran Kooperatif Tipe Numbered Heads Together (Nht) dan Tipe Two Stay Two Stray (Tsts) Pada Pembelajaran 
Matematika Ditinjau Dari Intelligence Quotient Siswa Kelas Viii Smp Di Kabupaten Purworejo Tahun Pelajaran 2011/2012 (Vol. 53). https://doi.org/10.1017/CBO9781107415324.004

Suwangsih, E., Budiarti, M. R., Ruskandi, K., Hendawati, Y., \& Majid, N. W. A. (2019). Two-stay two-stray model on improving mathematical communication skill of elementary school students. Journal of Physics: Conference Series, 1318(1). https://doi.org/10.1088/1742-6596/1318/1/012127

Turmuzi, M. (2017). Meningkatkan Kemampuan Berpikir Kritis Pada Perkuliahan Geometri Bilangan Kompleks Dengan Discovery learning Dipadukan Dengan Cooperative Learning Tipe NHT ( Numbered Head Together ). Prosiding Seminar ELPSA, (April), 57-67. Nusa Tenggara Barat: IKIP Mataram.

Umar, U., Kaharuddin, A., \& Erfan, M. (2020). A Comparative Study on Critical Thinking of Mathematical Problem Solving Using Problem Based Learning and Direct Intruction. Proceedings of the 1st Annual Conference on Education and Social Sciences (ACCESS 2019) A, 465(Access 2019), 314-316. Atlantis Press.

Winarti, A. (2016). Increasing Effectiveness of Number Head Together ( Nht ) Model Through Integration of Multiple Intelligences Theory in Chemistry Lesson. Proceeding Of 3rd International Conference On Research, Implementation And Education Of Mathematics And Science, (May), 16-17. 